\title{
Trichoderma asperellum efficiency in soybean yield components
}

Lillian França Borges Chagas', Aloisio Freitas Chagas Junior ${ }^{1 *}$, Rodrigo Ribeiro Fidelis', Magno Rodrigues de Carvalho Filho², Luciane de Oliveira Miller ${ }^{2}$

'Laboratory of Microbiology, Federal University of Tocantins, Gurupi, Tocantins, Brazil ${ }^{2} \mathrm{JCO}$ Fertilizers, Barreiras, Bahia, Brazil

*Corresponding author, e-mail: chagasjraf@uft.edu.br

\begin{abstract}
The present study aimed to evaluate the Trichoderma asperellum inoculation efficiency in agronomic performance of soybean plants under field conditions. Two experiments were conducted in a savanna in Gurupi, Tocantins, Brazil, during the 2013/2014 and 2014/2015 crop years, being realized soil chemical analysis and recording the climatic conditions. For the experiment, seeds from the cultivar Monsoy 9144 RR were used and the inoculation with $T$. asperellum were carried out with a powdered product with active ingredient based on Trichoderma (Trichoderma asperellum - UFT201), formulated with minimum viable concentration of conidia of $2 \times 10^{9} \mathrm{~g}^{-1}$, applied directly on the seeds $(20 \mathrm{~g} / \mathrm{kg}$ seed), in one of the treatments. Were evaluated the biomass, relative efficiency, initial and final stand, effectiveness or efficiency in the use of $T$. asperellum in maintaining the stand and yield. It was observed that with the use of the treatment with T. asperellum inoculation, the yield of both harvests were 8.5 and $9.1 \%$ higher, respectively, when compared to the treatment with no inoculation.
\end{abstract}

Keywords: Glycine max, biomass, yield

\section{Eficiência de Trichoderma asperellum nos componentes de produção de soja em campo}

\section{Resumo}

Este estudo teve como objetivo avaliar a eficiência da inoculação de Trichoderma asperellum no desempenho agronômico das plantas de soja em condições de campo. Dois experimentos foram conduzidos no cerrado em Gurupi, Tocantins, nas safras 2013/2014 e 2014/2015, sendo realizados análise química do solo e condições climáticas registradas durante período experimental. Os tratamentos foram constituídos por tratamento de sementes cultivar Monsoy 9144 RR, com e sem inoculação de T. asperellum com o produto em pó com o ingrediente ativo a base de Trichoderma (Trichoderma asperellum - UFT201), formulado com concentração mínima de de $2 \times 10^{9} \mathrm{~g}^{-1}$ conídios viáveis e aplicado diretamente sobre as sementes (dose de $20 \mathrm{~g} / \mathrm{kg}$ de semente). Foram realizadas avaliações de biomassa, eficiência relativa, estande inicial e final, eficácia ou eficiência no uso de $T$. asperellum e produtividade, sendo significativamente superiores para o tratamento com inoculação de T. asperellum, com produtividade para as duas safras sendo 8,5 e 9,1\% superiores, respectivamente, ao tratamento testemunha sem inoculação.

Palavras chave: Glycine max, biomassa, produtividade 
The use of chemicals such as fungicides for the control of soil diseases in agroecosystems has a very high cost, therefore, the integration of biological control techniques and agronomic practices that inhibit these phytopathogens are the best alternatives (Woo et al., 2014).

In the rhizosphere there are several microorganisms that can promote plant growth and protect the root system from infection by pathogens; such as the genus Trichoderma (Machado et al., 2012; Martínez et al., 2013). The species of the genus Trichoderma have received scientific and economic attention due to their antagonistic actions against various pathogens, such as parasitism, antibiosis and competition (Martínez et al., 2013). Some strains of Trichoderma increase the total area of the root system, enabling greater access to root mineral elements. Others are able to solubilize and make available to the plant the phosphate, iron, copper, manganese and zinc. In addition, it can improve the active mechanisms of macro and micronutrients absorption, as well as increase the efficiency of the plant to use some important nutrients as nitrogen (Shoresh et al., 2010; Machado et al., 2012).

In order to achieve higher economic returns with the increase in the biomass and yield of strategic crops for the Tocantins savannah, such as soybeans, it is necessary to continue the process of generating information, mainly from research, seeking to obtain and evaluate innovative management practices, such as the use of inoculants based on Trichoderma, focusing on the efficiency in the biological control of diseases and as plant growth promoters. Thus, the aim of the present study was to evaluate the Trichoderma spp. inoculation efficiency in the agronomic performance of soybean plants under field conditions.

Two field experiments with soybean were performed in a savanna in Gurupi, Tocantins, Brazil $\left(1^{\circ} 43^{\prime} 45^{\prime \prime}\right.$ South latitude and $49^{\circ} 04^{\prime} 07^{\prime \prime}$ West longitude and altitude of 280 meters), harvesting the cycle of 2013/2014 (December 2013 to May 2014), and 2014/2015 (December 2014 to May 2015). The soil of the experimental area was classified as a Red Yellow dystrophic Latossol with medium texture. The local climate is humid tropical, with little water deficiency (BIwA'a') and presenting a Savannah Tropical vegetation, according to Köppen- Geiger (Peel et al., 2007).

Soil chemical analysis and its interpretation were realized before the experiment implementation in the first growing season (first study), where the following values were observed: $2.04 \mathrm{cmol}_{\mathrm{c}} \mathrm{dm}^{-3}$ of calcium (Ca); $0.32 \mathrm{cmol}_{\mathrm{c}} \mathrm{dm}^{-3}$ of magnesium (Mg); $0.12 \mathrm{cmol}_{\mathrm{c}}$ $\mathrm{dm}^{-3}$ of potassium $(\mathrm{K}) ; 2.09 \mathrm{mg} \mathrm{dm}^{-3}$ of phosphorus (P); $0.04 \mathrm{cmol}_{\mathrm{C}} \mathrm{dm}^{-3}$ of aluminum (Al); $5.9 \mathrm{cmol}_{\mathrm{c}}$ $\mathrm{dm}^{-3}$ for cation exchange capacity (CTC); 2.48 $\mathrm{cmol}_{\mathrm{c}} \mathrm{dm}^{-3}$ for the sum of bases (SB); $30 \%$ of base saturation (\%V); $\mathrm{pH} 5.4$ in water; $1.0 \%$ of organic matter, texture of $72.3 \%, 8.2 \%$ and $19.5 \%$ for sand, silt and clay, respectively. In these experiments, the sowing fertilization (NPK $+\mathrm{S}+\mathrm{Ca}+$ Micro) was based on soil analysis, which recommended the application of $400 \mathrm{~kg} \mathrm{ha}^{-1}$ of the 5-25-15 formulation. The preparation of the area was realized by the conventional method, using disc plows, with two leveling operations aiming the standardization of the area, with use of leveling harrow and grooving by furrower of rows, adopting groove depth of $10 \mathrm{~cm}$ and space of $50 \mathrm{~cm}$ between rows. The Monsoy 9144 RR cultivar was used, with 15 seeds per linear meter, aiming at the end 12 plants per linear meter.

The experiment was carried out in a randomized blocks design, with four repetitions. The treatments were composed by seed treatments with or without (control) Trichoderma asperellum inoculation. Each plot was constituted by eight rows of $6 \mathrm{~m}$, with the spacing between rows of $0.5 \mathrm{~m}, 1 \mathrm{~m}$ between plots and $1 \mathrm{~m}$ between blocks, totaling $24 \mathrm{~m}^{2}$ for each experimental plot. The soybean seeds were inoculated with rhizobia (Bradyrhizobium sp.).

For the treatment with $T$. asperellum as inoculant powder was used the Isolated UFT 201: DQ381958 GenBank access, selected due to its potential for biocontrol and as plant-growth promoter. The inoculant was formulated with a minimum viable conidia concentration of $2 \times 10^{9}$ $\mathrm{g}^{-1}$ in JCO Fertilizers (Barreiras, BA, Brazil, with kaolin composition). The inoculant was applied directly on the seeds at planting with a dose of $20 \mathrm{~g}$ per $\mathrm{Kg}$ of seeds. During the crop development, all agronomical and phytosanitary managements 
needed were carried out.

The biomass evaluations were realized at 25 and 50 days after planting (DAP) in rows. For initial and final stand and yield evaluations, the central useful area of $6 \mathrm{~m}^{2}$ was used. The efficiency of the use of $T$. asperellum in the stand maintenance was calculated using the equation: $\mathrm{E} \%=\left\{1-\left[\mathrm{T}_{\mathrm{i}} / \mathrm{T}_{\mathrm{c}}\right]\right\} \times 100$, where, $\mathrm{E} \%$ = treatment efficiency; $\mathrm{Ti}=$ average $\%$ for the treatment final stand; $\mathrm{Tc}=\%$ average for the final stand in the control treatment. For each biomass evaluation, six plants per plot were harvested. The aerial part was separated from the roots with a cut made at the stem base and the nodules were removed and counted. Subsequently the shoot, root and the nodules were placed in paper bags dried in an oven at $65^{\circ} \mathrm{C}$, until constant weight.

The biomass assessment was done through the shoot dry matter (SDM), root dry matter (RDM), total dry matter (TDM), number of nodules (NN) and nodules dry matter (NDM). Using the biomass of aerial part during the evaluation at 50 DAP, the relative efficiency
(RE) was calculated according to the formula: RE $=(S D M$ with Trichoderma/DMAP without Trichoderma) $\times 100$. The grain yield was obtained in the useful area of $6 \mathrm{~m}^{2}$. Then, the pods were manually threshed, correcting the grain moisture to $14 \%$. After harvest, the yield per hectare was quantified. The data was submitted to variance analysis and Anova by Duncan's test at 5\% of probability using the Assistat version 7.7 beta software.

In the first experiment, the 2013/2014 harvest, the biomass at 25 DAP was significant different $(p<0.05)$ for the treatments RDM and TDM. For the evaluation at 50 DAP, all biomass and nodulation variables presented higher values $(p<0.01$ and $p<0.05)$ when the treatment with Trichoderma inoculation was used (Table 1).

For the harvest 2014/2105, the biomass and nodulation results at 25 DAP were higher $(p<0.05)$ for TDM. At 50 DAP there was a significant difference for biomass and nodulation, with higher values $(p<0.05)$ for the treatment with Trichoderma inoculation (Table 2).

Table 1. Shoot dry matter (SDM), root dry matter (RDM), total dry matter (TDM), number of nodules (NN) and nodules dry matter (NDM) in Monsoy 9144 RR soybean inoculated with Trichoderma asperellum in Gurupi, TO, Brazil in the $2013 / 2014^{1}$ harvest.

\begin{tabular}{|c|c|c|c|c|c|}
\hline \multirow{2}{*}{ Treatments } & SDM (g) & $\operatorname{RDM}(g)$ & TDM (g) & NN & $\mathrm{NDM}(\mathrm{mg})$ \\
\hline & \multicolumn{4}{|c|}{$25 \mathrm{DAP}^{2}$} & \\
\hline Without T. asperellum & $0.35 a$ & $0.11 \mathrm{~b}$ & $0.46 \mathrm{~b}$ & $10.5 a$ & $65 a$ \\
\hline With T. asperellum & $0.39 \mathrm{a}$ & $0.16 a$ & $0.55 a$ & $10.8 a$ & $76 a$ \\
\hline $\mathrm{CV}(\%)^{3}$ & 9.4 & 14.7 & 7.1 & $12.5^{\mathrm{s}}$ & 12.0 \\
\hline \multicolumn{6}{|c|}{$50 \mathrm{DAP}$} \\
\hline Without T. asperellum & $2.18 \mathrm{~b}$ & $0.27 b$ & $2.45 \mathrm{~b}$ & $19.8 \mathrm{~b}$ & $303 \mathrm{~b}$ \\
\hline With T. asperellum & $3.37 \mathrm{a}$ & $0.46 a$ & $3.83 a$ & $24.6 \mathrm{a}$ & $437 \mathrm{a}$ \\
\hline CV (\%) & 13.1 & 18.8 & 13.6 & 11.5 & 19.3 \\
\hline
\end{tabular}

Table 2. Shoot dry matter (SDM), root dry matter (RDM), total dry matter (TDM), number of nodules (NN) and nodules dry matter (NDM) in Monsoy 9144 RR soybean inoculated with Trichoderma asperellum in Gurupi, TO, Brazil in the 2014/2015' harvest.

\begin{tabular}{|c|c|c|c|c|c|}
\hline \multirow{2}{*}{ Treatments } & $\operatorname{SDM}(g)$ & RDM (g) & TDM (g) & NN & NDM (mg) \\
\hline & \multicolumn{5}{|c|}{$25 \mathrm{DAP}^{2}$} \\
\hline Without T. asperellum & $0.45 a$ & $0.18 a$ & $0.63 \mathrm{~b}$ & $14.5 a$ & $95 a$ \\
\hline With T. asperellum & $0.59 a$ & $0.19 a$ & $0.78 a$ & $16.8 \mathrm{a}$ & $96 a$ \\
\hline \multirow[t]{2}{*}{$\mathrm{CV}(\%)^{3}$} & 11.4 & $24.7^{\mathrm{s}}$ & 12.1 & 13.5 & 11.0 \\
\hline & \multicolumn{5}{|c|}{$50 \mathrm{DAP}$} \\
\hline Without T. asperellum & $5.20 \mathrm{~b}$ & $0.37 \mathrm{~b}$ & $5.57 \mathrm{~b}$ & $20.8 \mathrm{~b}$ & $150 \mathrm{~b}$ \\
\hline With T. asperellum & $7.73 a$ & $0.60 a$ & $8.33 a$ & $32.0 \mathrm{a}$ & $257 a$ \\
\hline CV (\%) & 11.1 & 15.8 & 12.6 & 15.1 & 16.3 \\
\hline
\end{tabular}


For relative efficiency (RE) on soybean, a higher value $(p<0.01)$ was observed for the treatment with $T$. asperellum inoculation, with an increase of 56 and $49 \%$ for the $2013 / 2014$ and 2014/2015 harvests, respectively, when compared to control (Figure 1).

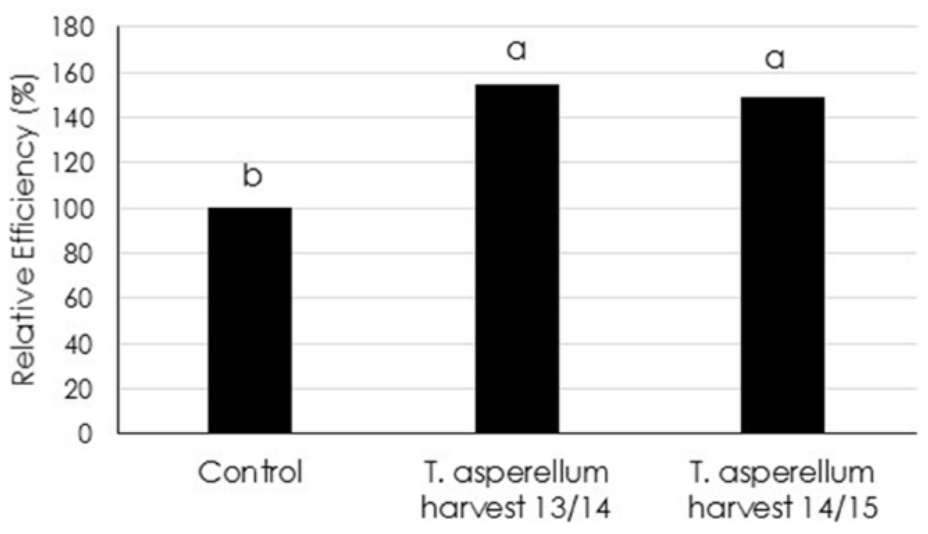

Figure 1. Relative efficiency (RE) of soybean at 50 DAP inoculated with Trichoderma asperellum compared to control (no inoculation). Harvest $2013 / 2014$ and $2014 / 2015$.

For the initial and final stand in the harvest 2013/2014, no significant difference between treatments was observed. For the 2014/2015 harvest, a significant difference for the final stand (Table 3) was observed. In the case of survival and efficiency using the treatment with $T$. asperellum inoculation, it was evident the effect of inoculation presenting higher values $(p<0.05)$ when compared to 'no inoculation' treatment, during the two evaluated crop years, with efficiency of 10 and $13.3 \%$, respectively.
For yield, the two harvests resulted in significant difference between the treatments, with a production of 44.8 sacks per hectare with the use of $T$. asperellum, $8.5 \%$ higher than the control, which presented 41.3 sacks per hectare, resulting in an increase of 3.5 sacks per hectare for the $2013 / 2014$ harvest. For the 2014/2015 harvest, the yield obtained was 40.9 sacks per hectare with $T$. asperellum, a value $9.1 \%$ higher than the control, which presented 37.5 sacks per hectare, resulting in an increase of 3.4 sacks per hectare (Table 3).

Table 3. Initial stand (IS), final stand (FS), survival, efficiency and yield of Monsoy 9144 RR soybean inoculated with Trichoderma asperellum, in Gurupi, TO, Brazil for the 2013/2014 and 2014/2015 harvests.'

\begin{tabular}{cccccc}
\hline Treatments & IS & FS & Surv. $(\%)^{2}$ & Effic. (\%) & Yield $\left(\mathrm{Kg} \mathrm{ha}^{-1}\right)$ \\
\cline { 2 - 6 } & \multicolumn{5}{c}{$2013 / 2014$ harvest } \\
\hline Without T. asperellum & $30.3 \mathrm{a}$ & $27.0 \mathrm{a}$ & $75.0 \mathrm{~b}$ & $2,475 \mathrm{~b}$ \\
With T. asperellum & $32.1 \mathrm{a}$ & $29.7 \mathrm{a}$ & $82.5 \mathrm{a}$ & 10.0 & $2,690 \mathrm{a}$ \\
CV (\%) ${ }^{4}$ & 10.8 & 11.7 & 11.1 & - & 14.3 \\
\hline & \multicolumn{5}{c}{$2014 / 2015$ harvest } \\
Without T. asperellum & $28.1 \mathrm{a}$ & $25.0 \mathrm{~b}$ & $69.4 \mathrm{~b}$ & $2,250 \mathrm{~b}$ \\
With T. asperellum & $29.1 \mathrm{a}$ & $28.3 \mathrm{a}$ & $78.6 \mathrm{a}$ & 13.3 & $2,454 \mathrm{a}$ \\
CV (\%) & 7.8 & 8.7 & 8.9 & 13.1 \\
\hline Averages followed by same lowercase letter in columns are not different according to Duncan's test at 5\% of significance. 2Plant survival, compared to
\end{tabular}

expected stand of 36 plants $m^{-2}$. ${ }^{3}$ Efficiency of $T$. asperellum in maintaining the stand. ${ }^{4}$ Coefficient of variation.

Some authors report positive results with Trichoderma inoculation in soybean. Milanesi et al. (2013) concluded that Trichoderma isolates act as soybean seedling growth promoters. Guareschi et al. (2012) in a study with the inoculation with Trichoderma spp. for seed treatments (200 mL to $50 \mathrm{Kg}$ of seeds) and soil application through $\left(1 \mathrm{~L} \mathrm{ha}^{-1}\right)$ at 10 days after emergence concluded that the Trichoderma spp. application promoted the sunflower and soybean shoot and root growth.

Trichoderma fungus has cited the as a plant growth promoter and studies have been conducted regarding the production of antimicrobial substances, ensuring a broad spectrum of activity against different pathogens, 
in which some strains of Trichoderma promote plant growth due to increased nutrient availability and growth hormone production (HoyosCarvajal et al., 2009; Shoresh et al., 2010; Azarmi et al., 2011; Guareschi et al., 2012). The root colonization often increases root development, crop productivity and resistance to abiotic stresses and improves nutrients use (Rubio et al., 2014).

The biological control in diseases through genetic and biochemical knowledge is well defined. However, little is known about the real effects and growth promoting mechanisms of inoculated plants by Trichoderma. Studies show strains with efficiency for the biocontrol of several pathogens or in plant growth promotion via rhizosphere colonization, under natural and axenic conditions (Pomella \& Ribeiro, 2009) or providing nutrients to the plant (Machado et al., 2012; Martínez et al., 2013). These findings aid in understanding the role of Trichoderma in natural or cultivated ecosystems and promote their use in agriculture. Studies performed using isolates with potential for antagonism have shown their ability to control diseases. However, the efficiency level verified in many field studies is lower than the expected. According to Pomella \& Ribeiro (2009), some factors are important for achieving effective results with the biocontrol agents, such as: effective strains in field against several phytopathogens, low production cost involving the efficient formulations, form, dose and time of application. However, in this study the soybean inoculation with $T$. asperellum transformed the potential of this inoculant as plant growth promoter in reality for the climate and soil conditions of the savanna region in Gurupi, Tocantins, Brazil.

\section{References}

Azarmi, R., Hajiegharari, B., Giglou, A. 2011. Effect of Trichoderma isolates on tomato seedling growth response and nutrient uptake. African Journal of Biotecnology, 10:5850-5855.

Guareschi, R. F., Perin, A., Macagnan, D., Tramontini, A., Gazolla, P. R. 2012. Emprego de Trichoderma spp. no controle de Sclerotinia sclerotiorum e na promoção de crescimento vegetativo nas culturas de girassol e soja. Global Science and Technology 05:01-08.
Hoyos-Carvajal, L., Orduz, S., Bissett, J. 2009. Growth stimulation in bean (Phaseolus vulgaris L.) by Trichoderma. Biological Control 51:409-416.

Machado, D. F. M., Parzianello, F. R., Silva, A. C. F., Antoniolli, Z. I. 2012. Trichoderma no Brasil: O fungo e o bioagente. Revista de Ciências Agrárias 35:274-288.

Martínez, B., Infante, D., Reyes, Y. 2013. Trichoderma spp. y su función en el control de plagas en los cultivos. Revista de Protección Vegetal 28:1-11.

Milanesi, P. M., Blume, E., Muniz, M. F. B., Reiniger, L. R. S., Antoniolli, Z. I., Junges, E., Lupatini, M. 2013. Detecção de Fusarium spp. e Trichoderma spp. e antagonismo de Trichoderma sp. em soja sob plantio direto. Semina: Ciências Agrárias 34:32193234.

Peel, M. C., Finlayson, B. L., McMahon, T. A. 2007. Update world map of the Köppen-Geiger climate classification. Hydrology and Earth System Science 11:1633-1644.

Pomella, A. W. V., Ribeiro, R. T. S. 2009. Controle biológico com Trichoderma em grandes culturas - uma visão empresarial. In: W. Bettiol, M. A. B. Morandi (Eds.) Biocontrole de doenças de plantas: uso e perspectivas. Embrapa Meio Ambiente. Jaguariúna, Brasil. p. 239-244.

Rubio, M. B., Quijada, N. M., Pérez, E., Domínguez, S., Monte, E., Hermosa, R. 2014. Identifying beneficial qualities of Trichoderma parareesei for plants. Applied and Environmental Microbiology 80:1864-1873

Shoresh, M.; Harman, G. E.; Mastouri, F. 2010. Induced systemic resistance and plant responses to fungal biocontrol agents. Annual Review Phytopathology 48:21-43.

Woo, S. L., Ruocco, M., Vinale, F., Nigro, M., Marra, R., Lombardi, N., Pascale, A., Lanzuise, S., Manganiello, G., Lorito, M. 2014. Trichodermabased Products and their Widespread Use in Agriculture. The Open Mycology Journal 8:71126. 